\title{
NEGATIVE EXTERNALITIES OF GOVERNMENT
}

\author{
WILLIAM BARNET II* \\ WALTER BLOCK** \\ JERRY DAUTERIVE***
}

\begin{abstract}
Resumen: Los economistas neoclásicos han utilizado durante mucho tiempo el concepto de "fallo de mercado" como un bastón con el que golpear sobre el sistema de libre empresa. Principalmente entre los llamados «fallos de mercado» se encuentran las «externalidades negativas». Estas se definen como acciones que afectan negativamente a terceras partes por vías distintas a los precios. El ejemplo clave es la polución. Sin embargo, estos «tristes» científicos nunca mencionan el hecho de que el propio gobierno es la fuente de las propias externalidades negativas, particularmente a través de la socialización del riesgo; por ejemplo, la seguridad social, los seguros médicos estatales, los seguros de enfermedad, los seguros de desempleo, la asistencia social, etc. El presente trabajo se dedica a explicar y ampliar el concepto de fallo del gobierno.
\end{abstract}

Palabras clave: Externalidad, bien público, fallo de mercado, efecto de vecindario, fallo del gobierno, riesgo moral.

Clasificación JEL: Q5; D62; H41.

Abstract: The neoclassical economists have long used the concept of «market failure» as a stick with which to beat up on the free enterprise system. Foremost amongst these so called «market failures» are «negative externalities.» These are defined as action that negatively affects third parties, other than via price. The key example is pollution. These dismal scientists never mention, however,

* Chase Distinguished Professor of International Business and Professor of Economics. Joseph A. Butt, S. J. College of Business Administration. Loyola University New Orleans, 6363 St. Charles Ave. New Orleans, LA 70118. (504) 864-7950, wbarnett@loyno.edu

** Harold E. Wirth Eminent Scholar Endowed Chair and Professor of Economics. Joseph A. Butt, S.J. College of Business Administration. Loyola University New Orleans, 6363 St. Charles Avenue, Box 15, Miller Hall 318 New Orleans, LA 70118. c.v.: http:/ / www.cba.loyno.edu/faculty.html (504) 864-7934, wblock@loyno.edu

*** Associate Professor of Economics. Loyola University New Orleans, 6363 St. Charles Ave. New Orleans, La. 70118. Dauterive@loyno.edu

Procesos de Mercado: Revista Europea de Economía Política Vol. VII, n. ${ }^{\circ}$ 1, Primavera 2010, pp. 215 a 238 
the fact that government itself is the source of negative externalities itself, particularly through the socialization of risk; e.g., social security, Medicare, Medicaid and other forms of socialized medicine, unemployment insurance, welfare, etc. The present paper is devoted to explicating and elaborating upon the concept of government failure.

Key words: Externality, public good, market failure, neighborhood effect, government failure, moral hazard.

JEL Classification: Q5; D62; H41.

\section{INTRODUCTION}

There is a hoary tradition of «market failure» alive and kicking in mainstream economics. ${ }^{1} \mathrm{~A}$ key element in this regard is the problem of externalities. ${ }^{2}$ The neoclassical economists define externalities as action that affects third parties. They offer a breakdown into negative and positive externalities. In the former case of negative externalities, or external diseconomies, $\mathrm{A}$ is dealing with $\mathrm{B}$ and in so doing negatively impacts or harms $\mathrm{C}$. The typical example offered in such contexts is pollution. ${ }^{3}$ In the latter case of positive externalities, or external economies, A is dealing with $B$ and in so doing positively impacts or helps $C$. The typical example trotted forth in such contexts is painting the exterior of a house, which improves the neighborhood, ${ }^{4}$ and thus raises the values of the surrounding homes. ${ }^{5}$

\footnotetext{
1 Bator (1958); Medema (2004); Pigou (1932).

2 Buchanan (1975); Brennan and Buchanan (1985); Canterbury and Marvasti (1992); Cornes and Sandler (1986); Friedman (1962, 30-32); Holcombe (1994); Mueller (1996); Olson (1971); Sandler, (1992).

3 For an utter evisceration of this doctrine, see Rothbard (1982 [1990]).

4 Rothbard's $(1997 b, 178)$ reductio ad absurdum of this situation is as follows: «A and B often benefit, it is held, if they can force C into doing something. ... [A]ny argument proclaiming the right and goodness of, say, three neighbors, who yearn to form a string quartet, forcing a forth neighbor at bayonet point to learn and play the viola, is hardly deserving of sober comment.»

5 Another distinction is between pecuniary and non pecuniary externalities. In the case of the house painting, the former would focus on the fact that everyone else's
} 
The authors of the present paper start from the premise that this is all arrant nonsense. ${ }^{6}$ The truth of the matter is that all supposed negative externalities are instead property rights violations, ${ }^{7}$ and positive ones are impossible to discern, as all human action is subjective. ${ }^{8}$ In any case, "one man's meat is another man's poison.» The distinction between positive and negative externalities is arbitrary and capricious.

However, we wish not to throw out this particular bit of bathwater with the bathwater, but instead to keep it, so that we can arguendo apply this doctrine not to the market to which it has been traditionally limited, but rather to government, so as to break new ground. Accordingly, this paper is devoted to an examination of cases where government is guilty of imposing external diseconomies on the populace. Given (the contrary to fact conditional) that externalities are a coherent concept, we shall demonstrate that in carrying out its duties, government imposes harm on third parties.

One category of acts we shall examine, in section II, is the socialization of risk; e.g., social security, Medicare, Medicaid, unemployment insurance, where government imposes risks on members of society. In section III we shall look at a second group of statist depredations, where the government undervalues the time or other resources of the citizenry. Under this rubric we look at the draft, jury duty, rent control, the post office, the motor vehicle bureau, affirmative action requirements on hiring, filling out tax forms, and the withholding tax. Section IV is devoted to a discussion of possible solutions to these problems. We conclude in section $\mathrm{V}$.

house (slightly) increases in value, while the latter would highlight the fact that those living in the neighborhood can now have more pleasant walks.

6 Anderson (1998); Block (1983, 1992 y 2003b); Callahan (2000); Cordato (1992); Cowen (1988); Guillory (2005); Higgs (1995); Hoppe (2003); Hummel (1990); MacKenzie (2002); North (1992); Rothbard (1985); Santoriello and Block (1996); Simpson (2005); Stringham (2002); Westley (2002).

7 Smoke pollution is akin to trespassing dust particles (Rothbard, 1982).

${ }^{8}$ Barnett (1989); Buchanan and Thirlby (1981); Buchanan (1969); Cordato (1989); DiLorenzo (1990); Garrison (1985); Gunning (1990); Kirzner (1986); Mises (1949); Rizzo (1979 y 1980); Rothbard (1979, 1993 and 1997a). 


\section{II}

\section{THE SOCIALIZATION OF RISK}

Moral hazard occurs when the economic actor for some reason need not bear the full risk of the loss of his property. With his incentives reduced, he takes less care of his possessions than would otherwise be the case. For example, if a man insures his car against theft or damage, he can be expected to take fewer precautions with regard to it, compared to the situation where he would be the sole loser were something untoward to occur. Now, the private insurance company ${ }^{9}$ can be expected to appropriately mitigate this danger contractually, by specifying in advance co payment and deductible options. To the extent it engages in such precautionary measures, the insurance firm will succeed and prosper; to the degree it does not, it will tend toward bankruptcy, and no longer concern us.

Matters are entirely different when it comes to the state, however. ${ }^{10}$ Its so called social security program ${ }^{11}$ encourages people to save less for their retirement years than they otherwise would have done. ${ }^{12}$ This impoverishes the entire economy, in addition to exacerbating risk. Public sector Medicare and Medicaid programs amount to no more than partial socialized medicine. ${ }^{13}$ They, too, encourage moral hazard. If a man knows he will have to pay the full costs of risky behavior, he will be more cautious than if he knows he can pass on some of the costs to others. This leads to decreases in the quality of diet, less exercise and other forms of private health care, more smoking, etc.

9 Block (1998b); Hoppe (1999, 2006); Semmens (1995).

10 Caplan $(2007,14)$ makes our point as follows: «Sensible public opinion is a public good. When a consumer has mistaken beliefs about what to buy, he foots the bill. When a voter has mistaken beliefs about government policy, the whole population picks up the tab.»

11 Ferrar (1982, 1985); Gruber and Wise (1999); Juurikkala (2007a, 2007b); MacKenzie (2007); Murphy (2005); Reisman (2005); Rockwell (2004); Rounds (2005); Sennholz (2004); Steinreich (1996).

12 Hulsmann (2003).

13 Block (2003a); Goodman and Musgrave (1992); Hamowy (1984); Herbener (1996); Hoppe (1993); Johnson, et. al. (1998); Laydon and Block (1996); Terrell, (2003). 
Unemployment insurance programs are also cases in point in this regard. If a man knows that a (significant) part of his earnings will be paid to him if he is jobless, he will not resist such a state of affairs as assiduously were this not the case. States Mises (1981, 440): «Unemployment doles can have no other effect than the perpetuation of unemployment.» And again (Mises, 1998, 776), «Assistance granted to the unemployed does not dispose of unemployment. It makes it easier for the unemployed to remain idle.» ${ }^{14}$ And the same applies to our welfare system. It, too, exacerbates, does not solve, poverty, by creating moral hazard conditions on the part of recipients. ${ }^{15}$

III

\section{UNDERVALUING THE TIME OR OTHER RESOURCES OF SOCIETY}

Another way in which the government perpetrates a so called external diseconomy on society at large is by undervaluing the time or other resources of it members.

\section{The draft}

The military draft wastes resources by allocating labor with very high alternative costs to jobs that could be filled by lesser valued inputs. Perhaps the most dramatic example of this phenomenon was the specter of Elvis Presley pushing a broom, or parade marching, when he could have been creating vast amounts of value as a singer, and could have been replaced in his military job by any number of thousands of men who could not replace him on stage. ${ }^{16}$

14 Canada spends roughly quadruple on a per capita basis on these programs as does the U.S. This accounts in part for the relative poverty of the former. See on this Block (1993); Anderson and Block (1993).

15 Anderson, G. (1987); Anderson M. (1978a); Brown (1987); Higgs (1995); LaBletta and Block (1999); Murray (1984); Olasky (1992); Rothbard (1998); Tucker (1984).

16 Anderson (1978b); Boudreaux (1993); Friedman (1967); Oi (1967a, 1967b). 
The cost of Private Presley was not his meager salary; it was the difference between that and the vastly greater amount of money he could have earned in the private sector.

\section{Jury duty}

A similar analysis applies to jury duty. Although, to be sure, not as great a violation of liberties nor a misallocation of resources, this practice still may be criticized on both these grounds.

\section{States Rothbard $(1978,99-100)$ :}

«... there is another cornerstone of the judicial system which has unaccountably gone unchallenged, even by libertarians, for far too long. This is compulsory jury service. There is little difference in kind, though obviously a great difference in degree, between compulsory jury duty and conscription; both are enslavement, both compel the individual to perform tasks on the State's behalf and at the State's bidding. And both are a function of pay at slave wages. Just as the shortage of voluntary enlistees in the army is a function of a pay scale far below the market wage, so the abysmally low pay for jury service insures that, even if jury "enlistments" were possible, not many would be forthcoming. Furthermore, not only are jurors coerced into attending and serving on juries, but sometimes they are locked behind closed doors for many weeks, and prohibited from reading newspapers. What is this but prison and involuntary servitude for noncriminals?

It will be objected that jury service is a highly important civic function, and insures a fair trial which a defendant may not obtain from the judge, especially since the judge is part of the State system and therefore liable to be partial to the prosecutor's case. Very true, but precisely because the service is so vital, it is particularly important that it be performed by people who do it gladly, and voluntarily. Have we forgotten that free labor is happier and more efficient than slave labor? The abolition of jury-slavery should be a vital plank in any libertarian platform. 
The judges are not conscripted; neither are the opposing lawyers; and neither should the jurors.

It is perhaps not a coincidence that, throughout the United States, lawyers are everywhere exempt from jury service. Since it is almost always lawyers who write the laws, can we detect class legislation and class privilege at work?»17

\section{The post office, and the motor vehicle bureau}

These two state functions misallocate resources and waste vast amounts of the time of the citizenry. Which of us has not had the experience of waiting on long slow moving queues, while the minions of the state were dismissive of our plight? It is no accident that the U.S. Post Office advises us to «mail early» and avoid the Christmas rush, thus catering to their own convenience, not that of the customers. In sharp contrast, it is the rare private enterprise that gives the back of its hand in this manner to those it serves. ${ }^{18}$

Mises (1944) refers to

«... the fanatical endeavors to transform the entire apparatus of production and distribution into a mammoth bureau. Lenin's ideal of taking the organization of the government's postal service as the pattern of society's economic organization and of making every man a cog in a vast bureaucratic machine makes it imperative to unmask the inferiority of bureaucratic methods when compared with those of private business... it is necessary to show ... why it would be mischievous to reorganize a bakery according to the pattern of the post office.» ${ }^{19}$

The typical motor vehicle bureau is practically a synonym for poor service to its clientele. They, after all, have no other

17 See on this also Armentano (1999); Ostrowski (2003); Rothbard (1967).

18 See Adie (1988, 1990a, 1990b; Alston, 2007); Bresiger (2004); Butler (1986); Moore, T. (1990); Moore, S. (1987); Priest (1975); Robbins (2000); Roberts (2005); Rockwell (2002).

19 http://www.mises.org/etexts/mises/bureaucracy/conclusion.asp. 
options when they wish to legally drive a car or truck. This lack of incentive - no such entity ever went broke in all of recorded history due to failure to satisfy customers - permeates this operation. ${ }^{20}$

\section{Affirmative action requirements on hiring}

These policies necessarily misallocate labor inputs. In their absence, employees would be allocated to job slots based on their productivity and hence profitability. In their presence, hiring decisions will be aimed in different directions. So there is economic waste involved here, even apart from the costs of monitoring, arbitrating and adjudicating employer decisionmaking in this regard.

There is one complication worth pursuing at this point. In the view of most commentators, without affirmative action, minority members would suffer from discrimination; they would be paid less than they «deserve.» In the opinion of others, this would not be the case: there is a tendency in the fully free market for all people, minority members specifically included, to be paid in accordance with their discounted marginal revenue productivity. ${ }^{21}$

Let us suppose, arguendo, that the former perspective is correct. Posit, then, that the discriminated against group, left handed red heads, has a productivity level of $\$ 10$ per hour, and is only paid $\$ 7$. All other members of society with that level of productivity are compensated at the rate of $\$ 10$. We may suppose that this result stems from two sources. There are some members of the majority community who will not hire a member of this despised group at any wage. There are others who will do so, but only at lower levels of compensation that will keep left handed red heads «in their place.» We assume away any and all market forces that would rend asunder our suppositions.

20 Block (2001)

21 Block (1992, 1998a); Block and Williams (1981); Epstein (1992); Levin (1987); Mattei (2004); Rockwell (2003); Rothbard (1978); Sowell (1975, 1982, 1994); Williams $(1982 a, 1982 b)$. 
Even if this is the case, it by no means follows that resources are misallocated in the absence of affirmative action. Take a specific case. Firm A offers B, a left handed red head, a salary of $\$ 7$. They «exploit» him to the tune of $\$ 3$ per hour. Has A violated any rights of $B$ ? Not a bit of it, unless we assume that $B$ has a right to A's wealth. Has A worsened the economic position of B? It is difficult to see how a case can be made out to support this claim. For from the fact that B accepted this offer we are entitled to deduce that other things equal, this was the best opportunity available to him. It cannot be denied that $B$ would have been even better off if $A$ had granted him a position in the firm at $\$ 10$. But, by the same token, B would have been even more better off so to speak, if the wage offer had been for $\$ 20, \$ 50$, or $\$ 100$ or more. The same could be said for all of us, no matter how much we are earning: it is always possible to contemplate made even better off. This applies to Bill Gates, the richest man in the world. The fact that $B$ is being paid less than he could have been under other scenarios, does not demonstrate that he is being dealt with unjustly, or is being exploited. Thus, affirmative action is a waste of and a misallocation of resources even under the heroic assumptions we have been entertaining.

\section{Filling out tax forms and the withholding tax}

Filling out tax forms takes time, time that has alternative costs. The more complex is the tax system, of course, the more time and energy it takes to comply with it. Tax simplification is opposed by the usual suspects: people who do well out of the present system, such as lawyers, tax accountants, etc., and their political allies.

Of course, the simplest tax possible is no tax at all. Here, government «services» would be turned over to the more efficient private sector of the economy. One barrier to a move in this direction is the system of tax withholding. ${ }^{22}$ Imagine if the entire year's

22 Vance (2005a, 2005b, 2006). 
tax burden were due in one fell swoop. The citizenry would be outraged at how much of their time and effort is spent for governmental operation. Under present institutional arrangements, almost the opposite occurs: people look forward to April 15, for then they are supposedly the beneficiaries of the tax system: they often get a «refund.»

Instrumental is setting up tax withholding was Milton Friedman. He did, however, have the grace (Friedman, 1998, tba) to regret these earlier actions of his.

\section{Traffic congestion}

To say that traffic congestion is a vast time waster would be an understatement of epic proportions. The Long Island Expressway in New York has been called the world's longest parking lot. There are estimates to the effect that the fastest way to get around most cities is by bicycle; ${ }^{23}$ that urban traffic moved faster in the horse and buggy days than at present. Gridlock is not an unknown phenomenon. Traffic congestion is very costly. ${ }^{24}$

Why do we have congested traffic? It is not because population rises, and automobile usage has outstripped a more slowly increasing stock of roads and highways. Were that all there were to the issue, the price of street usage would have risen. When demand increases for bread, circuses, indeed, for anything, the result is invariably a price rise. The only time there is a shortage, is when price is prevented from increasing. In the case of «ordinary» goods and services, this emanates from price controls and anti gouging measures. In the roadway situation, it is because no prices at all are charged for usage (Block, 1980).

There is no difference in principle between highway and street usage in the U.S. on the one hand, and long queues for numerous goods and services in the bad old U.S.S.R. Roads in

\footnotetext{
${ }^{23} \mathrm{http}:$ / / www.google.ca / search?hl=en\&q=fastest+way+to+get+around +most+ cities + is + by + bicycle\&btnG $=$ Google + Search\&meta $=$.

24 http://www.tc.gc.ca/mediaroom/releases/nat/2006/06-h006e.htm; http: / / www.ntweek.org/publications/ARTBA_Congestion.pdf.
} 
the former are equivalent to a «sovietization» of this amenity. ${ }^{25}$ Long waiting lines.

\section{SOLUTIONS}

There are two possible ways to address the cases of government failure discussed above. If the state is encouraging people to waste their time and resources, to make themselves dependent on the rest of us through welfare and other such programs, one of these paths leads to further limitations of liberty, the other to a continuation of the tyranny.

Relevant here is Mises' insight to the effect that each governmental intervention leads to others, in a widening circle, until we finally arrive at full socialism, unless we reverse positions and pull back from this precipice. States Mises (1952, tba):

«The government believes that the price of a definite commodity, e.g., milk, is too high. It wants to make it possible for the poor to give their children more milk. Thus it resorts to a price ceiling and fixes the price of milk at a lower rate than that prevailing on the free market. The result is that the marginal producers of milk, those producing at the highest cost, now incur losses. As no individual farmer or businessman can go on producing at a loss, these marginal producers stop producing and selling milk on the market. They will use their cows and their skill for other more profitable purposes. They will, for example, produce butter, cheese or meat. There will be less milk available for the consumers, not more. This, or course, is contrary to the intentions of the government. It wanted to make it easier for some people to buy more milk. But, as an outcome of its interference, the supply available drops. The measure proves abortive from the very point of view of the government and the groups it was eager to favor. It brings about a state of affairs, which - again from the point of view of the government - is even less desirable

25 Another analogy are long waiting lists for medical service in countries with socialized health care. 
than the previous state of affairs which it was designed to improve.»

«Now, the government is faced with an alternative. It can abrogate its decree and refrain from any further endeavors to control the price of milk. But if it insists upon its intention to keep the price of milk below the rate the unhampered market would have determined and wants nonetheless to avoid a drop in the supply of milk, it must try to eliminate the causes that render the marginal producers' business unremunerative. It must add to the first decree concerning only the price of milk a second decree fixing the prices of the factors of production necessary for the production of milk at such a low rate that the marginal producers of milk will no longer suffer losses and will therefore abstain from restricting output. But then the same story repeats itself on a remoter plane. The supply of the factors of production required for the production of milk drops, and again the government is back where it started. If it does not want to admit defeat and to abstain from any meddling with prices, it must push further and fix the prices of those factors of production which are needed for the production of the factors necessary for the production of milk. Thus the government is forced to go further and further, fixing step by step the prices of all consumers' goods and of all factors of production - both human, i.e., labor, and material - and to order every entrepreneur and every worker to continue work at these prices and wages. No branch of industry can be omitted from this all-round fixing of prices and wages and from this obligation to produce those quantities which the government wants to see produced. If some branches were to be left free out of regard for the fact that they produce only goods qualified as non-vital or even as luxuries, capital and labor would tend to flow into them and the result would be a drop in the supply of those goods, the prices of which government has fixed precisely because it considers them as indispensable for the satisfaction of the needs of the masses.»

Let us return to our example of the negative externalities of government. In this regard, we could pass further legislation to stop people from: 
- spending their hard earned money like a drunken sailor, because under our welfare system we would have make good their losses

- ruining their health (smoking, drinking booze, failing to brush their teeth, playing handball), because under our system of socialized medicine we would have make good their losses

- wasting their wealth (gambling), because under our system of welfare we would have make good their losses

- making errors in farming (planting the wrong crops), because under our system of farm subsidies we would have make good their losses

- making errors in banking (lending to the wrong people), because under our banking bailout system we would have make good their losses

- failing to save for a rainy day (compulsory savings plans), because under our system of welfare, pensions, we would have make good their losses

On the other hand, there is a completely different possible reaction to state encouraged «external diseconomies.» These, in contrast to the above set of policies, would increase freedom, not decrease it. All we need do is rescind all the legislation that makes it possible for the average man to act irresponsibly, at the expense of the rest of us. To wit, we would repeal welfare, social «security,» socialized medicine, farm subsidies, business bailouts, etc.

To this it could be objected that despite the best efforts of those who wish to roll back the Great Society, the New Deal, the Progressive period, and much, much more, it is unlikely in the extreme that these policies will disappear any time in the near future. True enough. ${ }^{26}$ But still, it is the necessary obligation of those who favor liberty not to call for erosion of liberties to gamble, smoke, save less than would be wise, etc. Instead, the only policy compatible with this perspective is to champion an end to the legislative enactments that encourage anti social behavior in the first place.

${ }^{26}$ Well, maybe not. The Berlin Wall fell very swiftly. So did the U.S.S.R. get deCommunized very abruptly. 
Let us consider in greater detail the issue of international trade, and the present U.S. deficit, which, it is claimed, is based not so much on imports of capital, or borrowing to support industrial growth, but rather on present frivolous consumption. According to critics, we as a nation are now living beyond our means. One such hypothetical critic addresses the balance of trade.

«When we say a country has a BOT deficit, we are not saying it has a deficit against one country offset by a surplus with another, rather we are saying that if we take the total of a country's deficits against various other countries and the total of its surpluses with various other countries, the net is a deficit. In the individual case, it would be as if an individual had deficits with Wal-Mart, local restaurants, etc. and surpluses with his employer but the total of all of his deficits exceeded that of all of his surpluses, on net. Now, whether or not that is a good thing depends upon the reason the net deficit is incurred. If it is to increase productivity, say, by buying equipment, then it would be a good thing in the sense that it would lead to higher sustainable levels of consumption. (I know that it is subjective on my part to think that a situation of higher sustainable levels of consumption is a good thing, especially as it may lead to that for many (most?) people in the country, but lead in the opposite direction for others, especially in the short run; nevertheless, I think nearly all economists would agree that higher sustainable levels of consumption are a good thing, especially if we factor in environmental quality as a consumer good.) On the other hand, it is a bad thing (see comment, supra, re subjectivity) if the deficit is financing current levels of consumption that cannot be sustained. The same applies to individuals as to a country. Why is the nation now running a net deficit? If it is to finance an education or training that will allow us to earn sufficiently higher incomes in the future it is a good thing, if it is merely to finance an extravagant lifestyle in the short run it is a bad thing. However, regardless of whether it is a good or a bad thing, such deficits are unsustainable in the long run unless they finance investment that increases productivity.»

«Or as they taught in the old days, self-liquidating debt is fine, but non-self-liquidating debt is the road to penury, save in a 
society with very liberal bankruptcy laws, in which case woe betide the creditors who make such loans, again, save in a society in which the government bails out such creditors, in which case God help the taxpayers.»

«In a free world I would support the right to spend oneself into penury, and that regardless of how many chose to act in such a manner. However, I would still maintain, as would be my right, that such behavior was bad/stupid/whatever. I would also note that as a matter of fact that such action is not sustainable over the long run. In the current reality, I do not agree that such actions by individuals, and the group of individuals we refer to as a country, should be allowed, as I am going to end up forced to pay for it. Of course, the solution is to have a free society, but given that we don't, I do not want people spending themselves into penury and then me and my family and friends being taxed to support them.»

Let us now take up matters from the other side of this debate. We can readily «concede» that there is indeed something wrong, very wrong, with running a net deficit. This occurs when the government forces or subsidizes this state of affairs. However, our critic of markets does not even contend that this is the case. But if net deficits are freely chosen human actions, then free enterprisers must, presumably, defend them, not characterize them as «bad.» 27

Support for this contention arises from a look at the time series of human life. During the earliest days, say age 0-16, most people run net deficits, at others' expense, usually their parents. «Woe betide» such parental debtors. Also, after retirement, most people also run net deficits, and reduce their wealth positions. Suppose an entire country does this, perhaps because the population is dominated by very young and very old people. Do we really want to abrogate their rights to make such decisions?

27 For a critique of the idea that greater wealth or economic growth is necessarily a good thing, see Kirzner, 1963. 


\section{$\mathrm{V}$ \\ CONCLUSION}

Our critic claims that «non-self-liquidating debt is the road to penury.» This cannot be denied. But, if this is the freely chosen decision of economic actors, there is no economic or ethical justification for stopping it through force of law. For those who maintain that this is bad or stupid behavior, it does not logically follow that this should be prohibited. Instead, it implies that no one should be forced to make good other people's bad, stupid behavior.

\section{BIBLIOGRAPHICAL REFERENCES}

Adie, D.K. (1988): Monopoly Mail: Privatizing the United States Postal Service, New Brunswick, N.J.: Transaction.

- $\quad$ (1990a): «Why Marginal Reform of the U.S. Postal Service Won't Succeed», in Free the Mail: Ending the Postal Monopoly, Peter J. Ferrara, ed., Washington, D.C.: The Cato Institute.

- (1990b): The Mail Monopoly: Analyzing Canadian Postal Service, Vancouver: The Fraser Institute.

Alston, W.D. (2007): «What Would Happen If the Post Office Had Competition?» June 6; http:/ / www.lewrockwell.com/ alston/alston21.html

Anderson, G.M. (1987): «Welfare Programs in the Rent Seeking Society», Southern Economic Journal, 54: 377-386.

Anderson, G.M. and Block, W. (1993): «Guaranteed Annual Unemployment: a comment on Derek Hum and Wayne Simpson», The Journal of Labor Economics, Vol. 11, N. ${ }^{\circ}$ 1, Part 2, January, pp. S348-S363.

Anderson, M. (1978a). Welfare: The Political Economy of Welfare Reform in the United States, Stanford: Hoover Institution.

- (1978b): The Voluntary Military, Stanford: Hoover Institution.

ANDERSON, W. (1998): «Market Failure?» October 8; http:// www.mises.org/story/53

Armentano, D.T. (1999): «Abolish Jury Duty», The Free Market. Vol. 17, N.o 8, August; http://www.mises.org/freemarket_ detail.asp?control $=14 \&$ sortorder $=$ articledate 
BARNETT II, W. (1989): «Subjective Cost Revisited», Review of Austrian Economics, Vol. 3, pp. 137-138.

BATOR, F.M. (1958): «The anatomy of market failure», Quarterly Journal of Economics 72 (August): 351-79.

BLOCK, W. (1980): «Congestion and Road Pricing», The Journal of Libertarian Studies: An Interdisciplinary Review, Vol. IV, N.․ 3, Summer, pp. 299-330.

- (1983): «Public Goods and Externalities: The Case of Roads», The Journal of Libertarian Studies: An Interdisciplinary Review, Vol. VII, N.o 1, Spring, pp. 1-34; http://www.mises.org/ journals/jls/7_1/7_1_1.pdf

- (1992): «Discrimination: An Interdisciplinary Analysis», The Journal of Business Ethics, Vol. 11, pp. 241-254. (14).

- (1993): «Worker's compensation and unemployment insurance in the U.S. and Canada: a comment on John Burton and Terry Thomason, Chris Bruce and Frank Atkins, Patricia M. Anderson and Bruce Meyer, David Green and Craig Riddell», The Journal of Labor Economics, Vol. 11, N.o 1, Part 2, January, pp. S305-S326.

- (1998a): «Compromising the Uncompromisable: Discrimination", American Journal of Economics and Sociology, Vol. 57, N.ㅇ 2, April, 1998, pp. 223-237. http:/ / www.babson.edu/ ajes/issues/past.htm

- (1998b): «Private Roads, Competition, Automobile Insurance and Price Controls», Competitiveness Review, Vol. 8, N.․ 1, pp. 55-64.

- (2001): «Motor Vehicle Bureau», September 12; http:// www.lewrockwell.com/block/block8.html

- (2003a): «Socialized Medicine is the Problem», Surgical Neurology, Vol. 60, ‥ 5, November, pp. 467-46.

- (2003b): «National Defense and the Theory of Externalities, Public Goods and Clubs», The Myth of National Defense: Essays on the Theory and History of Security Production, Hoppe, Hans-Hermann, ed., Auburn: Mises Institute, pp. 301-334; http:/ / www.mises.org/etexts/defensemyth.pdf

Block, W. and Williams, W.E. (1981): «Male-Female Earnings Differentials: A Critical Reappraisal», The Journal of Labor Research, Vol. II, N.o 2, Fall, pp. 385-388. 
Boudreaux, D. (1993): «A Life-Saving Lesson from Operation Desert Storm», The Freeman, October, Vol. 43, N.․10; http: / / www. libertyhaven.com/politicsandcurrentevents/publicjustice/ lifesaving.shtml

BRENNAN, G. and BuchanAN, J.M. (1985): The reason of rules: constitutional political economy, Cambridge: Cambridge University Press.

Bresiger, G. (2004): «Post Office Hell», December, 22; http:// www.mises.org/fullstory.aspx? $\mathrm{Id}=1696$

Brown, A. (1987): «The Shadow Side of Affluence: The Welfare System and the Welfare of the Needy," Fraser Forum, October.

Buchanan, J.M. (1969): Cost and Choice: An Inquiry into Economic Theory, Chicago: Markham.

- (1975): The Limits of Liberty: Between Anarchy and Leviathan, Chicago: University of Chicago Press.

BuchanAN, J.M. and ThirLby, G.F. (1981): L.S.E. Essays on Cost, New York: New York University Press.

Butler, S.M. (1986): «Privatizing Bulk Mail», Management, 6, N. $\stackrel{\circ}{1}$.

Callahan, G. (2000): «Market Failure Again?» April 4; http:// www.mises.org/story/407

Canterbury, E.R. and MARVASTI, A. (1992): «The Coase Theorem as a Negative Externality», Journal of Economic Issues, Vol. 26, N.o 4, December, pp. 1179-1189.

CAPLAN, B. (2007): The Myth of the Rational Voter: Why Democracies Choose Bad Policies. Princeton, N.J.: Princeton University Press.

CoRdato, R.E. (1989): «Subjective Value, Time Passage, and the Economics of Harmful Effects», Hamline Law Review, Vol. 12, N.․․ 2, Spring, pp. 229-244.

- (1992): Welfare Economics and Externalities in an Open-Ended Universe: A Modern Austrian Perspective, Boston: Kluwer.

CoRnes, R. and SANDLER, T. (1986): The Theory of Externalities, Public Goods and Club Goods, Cambridge: Cambridge University Press.

Cowen, T., ed. (1988): The Theory of Market Failure: A Critical Examination, Fairfax, VA: George Mason University Press. 
DiLorenZO, Th.J. (1990): «The Subjectivist Roots of James Buchanan's Economics», The Review of Austrian Economics, Vol. 4, 1990, pp. 180-195.

EpsteIN, R.A. (1992): Forbidden Grounds: The Case Against Employment Discrimination Laws, Cambridge: Harvard University Press.

FERRARA, P.J. (1982): Social Security: Averting the Crisis, Washington DC: Cato Institute.

- (1985) ed.: Social Security: Prospects for Real Reform, Washington DC: Cato Institute.

Friedman, M. (1962): Capitalism and Freedom, Chicago: University of Chicago Press

- (1967): «Why Not a Volunteer Army?» New Individualist Review, Vol. 4, Spring, pp. 3-9

Friedman, M. and Friedman, R.D. (1998): Two Lucky People, Chicago: University of Chicago Press

Garrison, R. (1985): «A Subjectivist Theory of a Capital Using Economy», in O'Driscoll, Gerald P. and Rizzo, Mario, The Economics of Time and Ignorance, Oxford: Basil Blackwell.

Goodman, J.C. and G.L. Musgrave (1992): Patient Power: Solving America's Health Care Crisis. Washington D.C.: Cato.

GrUber, J. and Wise, D.A. , eds. (1999): Social Security and Retirement Around the World, University of Chicago Press.

Guillory, G. (2005): «What Are You Calling Failure?» May 5; http:/ / www.mises.org/story/1806.

GunNING, J.P. (1990): The New Subjectivist Revolution: An Elucidation and Extension of Ludwig von Mises's Contribution to Economic Theory, Savage, MD: Rowan and Littlefield.

Hamowy, R. (1984): Canadian Medicine: A Study in Restricted Entry, Vancouver: The Fraser Institute.

Herbener, J. (1996): «Socialized Medicine, Take Two», The Free Market. Vol. 14, ‥ 7, July; http://www.mises.org/ freemarket_detail.asp? control=172\&sortorder=articledate

Higgs, R. (1995): «The Myth of "Failed" Policies», The Free Market. June. Vol. 13, N.o 6. http://www.mises.org/freemarket_ detail.asp?control $=239 \&$ sortorder $=$ articledate

Holcombe, R.G. (1994): The Economic Foundations of Government, New York: New York University Press. 
Hoppe, H.H. (1999): «The private production of defense», Journal of Libertarian Studies 14, N. 1 (Winter): 27-52.

- (1993): «A Four-Step Health-Care Solution», The Free Market. Vol. 11, N.o 4, April, pp. ; http:/ / www.mises.org/freemarket_ detail.asp? control $=279$.

- (2006): «Uncertainty and Its Exigencies: The Critical Role of Insurance in the Free Market», March 7; http:/ /www. mises.org/story/2021

- (2003) ed.: «National Defense and the Theory of Externalities, Public Goods and Clubs», The Myth of National Defense: Essays on the Theory and History of Security Production, Hoppe, Hans-Hermann, ed., Auburn: Mises Institute.

HulsmanN, J.G. (2003): «Facts and Counterfactuals in Economic Law», The Journal of Libertarian Studies. Vol. 17, ‥ 1, pp. 57-102.

Hummel, J.R. (1990): «National Goods Versus Public Goods: Defense, Disarmament, and Free Riders», 4 Rev. Austrian Econ. 88.

Johnson, C.; Block, W. and OxNer, Th. (1998): «Notes on Health Care Financing and Free Markets», Journal of Accounting, Ethics and Public Policy, Vol. 1, N.o 3, Summer 1998, pp. 488-502.

JunrikKala, O. (2007a). «Old-age Security Without the State», http:/ / www.mises.org/story / 2515

- (2007b): «Making Kids Worthless: Social Security's Contribution to the Fertility Crisis», January, 24; http:// www.mises.org/story/2451

KirzNer, I.M. (1963): «On the Premises of Growth Economics», New Individualist Review, Summer, Vol. 3, ‥ 1, pp. 20-28.

- (1986) ed.: Subjectivism, Intelligibility and Economic Understanding, New York: New York University Press.

LABLETTA, N. and BLOCK, W. (1999): «The Restoration of the American Dream: A Case for Abolishing Welfare», Humanomics, Vol. 15, N.. 4 , pp. 55-65.

LAYDEN, W.R. and Block, W. (1996): «Health Security», Nomos, July, N.. $47 / 48$, pp. 38-45.

Levin, M. (1987): Feminism and Freedom, New York: Transaction Books. 
MacKenzie, D.W. (2002): «The Market Failure Myth», August 26; http:/ / www.mises.org/fullstory.aspx?control=1035.

- (2007): «What If Social Security Were Completely Scrapped?» June 18; http:/ / www.mises.org/story / 2586.

MATTEI, E. (2004): «Employment at Will», April 28; http: / / www. mises.org/story/1502

Medema, S.G. (2004): «Mill, Sidgwick, and the Evolution of the Theory of Market Failure», July; http:/ / www.utilitarian.net/ sidgwick/about/2004070102.pdf.

Mises, L. von (1944): Bureaucracy. New Haven: Yale University Press.

- (1952): Planning for Freedom and Other Essays and Addresses; South Holland, Ill.: Libertarian Press; http:/ / www.mises.org/ midroad.asp.

- $\quad$ (1981 [1969]), Socialism, Indianapolis: Liberty Fund

- ([1949] 1998), Human Action, Scholars' Edition. Auburn: Mises Institute.

Moore, S. (1987): «Privatizing the U.S. Postal Service», in Stephen Moore and Stuart Butler, eds., Privatization, Washington: Heritage Foundation.

Moore, Th.G. (1990): «The Federal Postal Monopoly: History, Rationale, and Future», Free The Mail: Ending the Postal Monopoly ed. Peter J. Ferrara.Washington, D.C.: CATO Institute.

Mueller, D.C. (1996): Constitutional Democracy, Oxford: Oxford University Press.

MurPHY, R.P. (2005): «Bush's Impossible Social Security Plan», June 12; http:/ / www.mises.org/story/1813.

Murray, Ch. (1984): Losing Ground: American Social Policy from 1950 to 1980, New York: Basic Books.

North, G. (1992): The Coase Theorem, Tyler, TX: The Institute for Christian Economics.

OI, W.Y. (1967a): «The Real Costs of a Volunteer Military», New Individualist Review, Vol. 4, Spring, pp. 13-16.

- (1967b): «The Economic Cost of the Draft», American Economic Review, Vol. 57, May, pp. 39-62.

Olasky, M. (1992): The Tragedy of American Compassion, Chicago: Regnery Gateway. 
Olson, Jr., M. (1971): The Logic of Collective Action: Public Goods and the Theory of Groups, New York: Schocken Books.

Ostrowski, J. (2003): «What's Wrong with Juries», December 1; http:/ / www.mises.org/story/1383.

Pigou, A.C. (1932 [1920]): The Economics of Welfare, $4^{\text {th }}$ ed. London: Macmillan.

Priest, G. (1975): «The History of the Postal Monopoly in the United States», Journal of Law and Economics, Vol. 18, ‥ 33 , pp. 33-80.

Reisman, G. (2005): «Social Security Reform: A Free-Market Alternative», February, 21; http:/ /www.mises.org/story/ 1751.

Rizzo, M.J. (1979): «Uncertainty, Subjectivity, and the Economic Analysis of Law», in Mario J. Rizzo (ed.), Time, Uncertainty, and Disequilibrium, Lexington, MA: Lexington Books, pp. 71-90.

- (1980): «The Mirage of Efficiency», Hofstra Law Review, Vol. 8, pp. 641-658.

RobiINS, J.Ch. (2000): «The Post Office and E-Commerce», September 15; http://www.mises.org/story/506.

Roberts, T. (2005): «Postal Commissars to Raise Rates. Don't Complain», May 2; http:/ / www.mises.org/story/1812.

RockWelL, Jr., Ll.H. (2002): «Can the Market Deliver Letters?» December 17; http:/ / www.mises.org/story/1119.

- (2003): «Discrimination and Freedom», The Free Market. Vol. 21, N.o 4, April; http:/ / www.mises.org/freemarket_ detail.asp?control $=437 \&$ sortorder $=$ articledate

- (2004): «Save or else», December 12; http:/ / www.mises.org/ fullstory.aspx?Id=1695

RothbARD, M.N. (1967): «Abolish Slavery: Compulsory Jury Duty Also Is Draft», Orange County Register, August 3.

- (1978): For a New Liberty, New York: Macmillan.

- (1979): "Comment: The Myth of Efficiency», in Mario J. Rizzo (ed.), Time, Uncertainty, and Disequilibrium, Lexington, MA: Lexington Books: pp. 91-96.

- (1982): «Law, Property Rights, and Air Pollution», Cato Journal, Vol. 2, N.․ 1, Spring; reprinted in Economics and the Environment: A Reconciliation, Walter Block, ed., Vancouver: 
The Fraser Institute, 1990, pp. 233-279; http:/ / www.mises. org/rothbard/lawproperty.pdf

- (1985): «Airport Congestion: A Case of Market Failure?» The Free Market. Auburn, AL: The Ludwig von Mises Institute, January, http://www.mises.org/econsense/ ch52.asp

- (1993): Man, Economy, and State, Auburn AL: Ludwig von Mises Institute.

- (1997a): «Toward a Reconstruction of Utility and Welfare Economics», in The Logic of Action: Method, Money and the Austrian School, Vol. I, Cheltenham, UK: Edward Elgar.

- (1997b): "The Fallacy of the "Public Sector"», The Logic of Action: Applications and Criticism from the Austrian School, Vol. II, Cheltenham, UK: Edward Elgar.

- 1998 [1982]: «Welfare and the Welfare State», In The Ethics of Liberty, Atlantic Highlands, N.J.: Humanities Press, pp. 160-193; http:/ / www.mises.org/rothbard/ethics/ethics.asp

Rounds, Jr., Ch.E. (2005): «The Fiction of Social Security Bonds», May, 30; http:/ / www.mises.org/story/1820

SANDlER, T. (1992): Collective Action: Theory and Applications, Ann Arbor: The University of Michigan Press

Santoriello, A. and Block, W. (1996): «Externalities and the Environment», The Freeman, November, Vol. 46, N.ำ11, pp. 755-756; reprinted in El Diario, (Bolivia), July 1997.

Semmens, J. (1995): «Privatizing Vehicle Registrations, Driver's Licenses and Auto Insurance», Transportation Quarterly, Fall, Vol. 49, N. ${ }^{4}$, pp. 125-135.

Sennholz, H. (2004): «Distractions in the Social Security Debate», http:/ / www.mises.org/fullstory.aspx?Id=1686

Simpson, B. (2005): Markets Don't Fail, New York, N.Y.: Lexington Books.

Sowell, T. (1975): Race and Economics. New York: Longman.

SOWELL, Th. (1982): «Weber and Bakke and the presuppositions of "Affirmative Action"», Discrimination, Affirmative Action and Equal Opportunity, Walter Block and Michael Walker, eds., Vancouver: The Fraser Institute.

- (1994): Race and Culture: A World View. New York: Basic Book. 
SteinReich, D. (1996): «Social Security Reform: True and False», The Free Market. October, Vol. 14, Number 10; http:/ / www. mises.org/freemarket_detail.asp?control=160\&sortorder=ar ticledate.

Stringham, E. (2002): «The Emergence of the London Stock Exchange as a Self-Policing Club», Journal of Private Enterprise, Vol. 17, N.o 2, 1-19.

Terrell, T. D. (2003): «Socialized Medicine in America», The Free Market. Vol. 23, ‥o 11, November; http:/ / www.mises.org/ freemarket_detail.asp?control=458\&sortorder $=$ articledate

TUCKER, W. (1984), «Black Family Agonistes», The American Spectator, July, pp. 14-17.

VANCE, L. (2005): «The Curse of the Withholding Tax», April 21; http:/ / www.mises.org/story / 1797.

- (2005): «The Fair Tax Fraud», May 18; http:/ / www.mises.org/ story/1814.

— (2006): «Flat Tax Folly», April 14; http:/ / www.mises.org/ story $/ 2112$.

Westley, Ch. (2002): «The Myth of Market Failure», June 14; http://www.mises.org/story/982.

Williams, W. (1982b): «On Discrimination, Prejudice, Racial Income Differentials, and Affirmative Action», Discrimination, Affirmative Action and Equal Opportunity, Walter Block and Michael Walker, eds., Vancouver: The Fraser Institute.

Williams, W.E. (1982a). The State Against Blacks, New York, McGraw-Hill. 